\title{
Replacement of traditional emulsifying salts by selected hydrocolloids in processed cheese production
}

\author{
Michaela Černíková ${ }^{3}$, František Buňka ${ }^{*}$, Matěj Pospiech , Bohuslava Tremlová , Kristýna Hladkác, \\ Vladimír Pavlínek d, Pavel Březina ${ }^{3}$
}

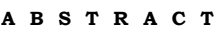

Different hydrocolloids were examined as possible replacements for traditional phosphate- and citrate- based emulsifying salts in processed cheese production. The following hydrocolloids (at concentrations in the final product of $<1.0 \%$, w/w) were chosen: modified starch (with bound sodium octenyl succinate), low methoxyl pectin (alone or combined with lecithin), locust bean gum, K-carrageenan and L-carra- geenan. The products were assessed by sensory analysis, microscopic image analysis and dynamic oscillatory rheometry. Modified starch, locust bean gum and low methoxyl pectin could not be recommended as replacements for traditional emulsifying salts. Model processed cheeses without traditional emulsifying salts of $\mathbf{4 0} \%(\mathrm{w} / \mathrm{w}$ ) dry matter and $55 \%$ (w/w) fat-in-dry matter containing $1.0 \%$ (w/w) iccarrageenan or i-carrageenan were found to be homogeneous, however the products were hard with fracturable texture.
\end{abstract}

\section{Introduction}

Processed cheeses and their analogs provide a good source of proteins, fats, minerals and vitamins in the diet. Traditionally, processed cheeses are produced by stirring at temperatures that usually range between 90 and $100{ }^{\circ} \mathrm{C}$ under a partial vacuum. Ingredients for the production of processed cheeses mainly include natural cheeses, butter, emulsifying salts and water (Guinee, Carič, \& Kaláb, 2004; Lu, Shirashoji, \& Lucey, 2007). During the production of processed cheeses, emulsifying salts play an important role and ensure that homogeneous products with desired consistency are made. The actual effect of emulsifying salts lies in the exchange of calcium cations of insoluble calcium paracaseinate for sodium ions, which leads to the formation of more soluble sodium paracaseinate (Mizuno \& Lucey, 2007). The application of emulsifying salts results in chain peptization, dispersion, hydration and swelling of proteins, and emulsification and stabilization of fat (Guinee et al., 2004; Lucey, Johnson, \& Horne, 2003). Sodium salts of phosphates and polyphosphates are most commonly used. The affinity to calcium ions rises with increasing chain length, which leads to increased peptization of casein. During the cooling stage in processed cheese manufacture the calcium ions help to form the final three-dimensional protein network (Guinee et al., 2004; Kawasaki, 2008).

Phosphorus is an essential nutrient; on the other hand excessive amounts of phosphorus may be detrimental to bone structure and could contribute to osteoporosis, especially when combined with low calcium consumption (Cashman, 2006). The optimal molar Ca:P ratio in the diet is 1:1 or higher (Buchman \& Moukarzel, 2000; Palacios, 2006). In processed cheese, the high amount of phosphorus reduces the Ca:P ratio (to 1:1.5-3.0), which could be implicated in osteoporosis (Schaffer, Lorinzy, \& Belágyi, 1999). Traditional emulsifying salts also contain a high concentration of sodium (up to $30 \%, \mathrm{w} / \mathrm{w}$ ). Nowadays, the high amount of sodium in human nutrition is considered a risk factor for many diseases (Palar \& Sturm, 2009).

With the aim of increasing the Ca:P ratio and decreasing the consumption of sodium and its compounds, attempts have been made to produce processed cheese or its analogs without the use of traditional phosphate- and polyphosphate-based emulsifying salts. Carič and Kaláb (1997) claimed that it is possible to produce stable processed cheese with half the amount of emulsifying salts by using approximately $1 \%$ monoglycerides. However, there are studies describing the complete substitution of emulsifying salts. Schaffer et al. (1999) and Schaffer, Szakály, Lórinczy, and Schaffer 
(2001) studied processed cheeses and their analogs that they had produced without using a mixture of orthophosphates and polyphosphates. As a substitute, they used a mixture of non-specified vegetable hydrocolloids. The products were acceptable for consumption (Schaffer et al 1 1999, 2001).

The successful substitution of traditional emulsifying salts by hydrocolloids allows: (i) reduction of the amount of phosphorus and an increase in the Ca: $\mathrm{P}$ ratio in processed cheese; (ii) reduction of the sodium concentration in processed cheese; (iii) utilization of biodegradable additives from renewable sources instead of phosphorus, an excess of which is generally considered a risk factor for the environment; (iv) establishment of new products with health benefits.

Hydrocolloids (polysaccharide- or protein-based) are used to form gels, stabilise foams, create and disperse emulsions, and decrease the formation of ice and sugar crystals. They are added to food products in very small amounts, usually less than $1.0 \%$. The most commonly used polysaccharide-based hydrocolloids are natural and modified starches, carrageenan, pectin, xanthan and locust bean gum. The most common protein hydrocolloids include gelatine, casein, caseinates and whey proteins (Dickinson, 2003; Tan, Ye, Singh, \& Hemar, 2007).

Polysaccharides are generally considered to be stabilizers of emulsions rather than true emulsifiers. On the other hand, some of these polymers possess surface activity, which could be derived from: (i) proteineous residues with hydrophobic amino acids bonded to polysaccharides, (ii) a propensity to reduce surface tension at low concentrations for some polysaccharides, (iii) a large increase of the viscosity of the continuous phase and thus decreasing the time required for coalescence of fat droplets, (iv) a small hydrophobic character of polysaccharides due to $-\mathrm{CH}$ or other (e.g., acetyl) groups (Benichou, Aserin, \& Garti, 2002; Garti \& Leser, 2001; Rinaudo, 2008). According to Dickinson (2003) and Nakauma et al. (2008), the surface activity of polysaccharides is especially attributable to the proteinaceous "moiety" of some polymers.

The initial aim of this work was to examine different hydrocolloids as replacements for traditional citrate-and phosphate- based emulsifying salts. Subsequently, our aim was to investigate the texture, rheological properties, and microstructure of processed cheese with hydrocolloids as replacements for emulsifying salts with the purpose of making homogeneous and stable processed cheese products.

\section{Materials and methods}

\subsection{Materials}

The following hydrocolloids were used: low methoxyl pectin, locust bean gum, ic-carrageenan and i-carrageenan (Sigma-Aldrich, St. Louis, MO, USA), modified starch with bound sodium octenyl succinate (Natura, Prague, Czech Republic), and low esterified pectin in combination with lecithin (Lucas Mayer, Inc., Decatur, IL, USA). The experimental plan is shown in Table 1 , with concentrations given per total weight of Edam cheese, butter and water (see Section 2.2 for manufacturing conditions). The feasibility of processing (under the conditions tested) was evaluated by sensory analysis with a minimum of two of a total of five trained assessors (described in Section 2.5). Any product that precipitated into two distinct phases (solid and liquid matter) was assessed as being not feasible for replacement of traditional emulsifying salts by the hydrocolloids tested. Homogeneity of the final processed cheese was analysed by means of sensory evaluation, image analysis and dynamic oscillatory rheometry. Only those combinations of hydrocolloids that showed homogeneity (evaluated by all three methods) were chosen for the subsequent study of gel formation
Table 1

Hydrocolloids and additional substances evaluated as replacements for traditional Hydrocolloids and additional substances ev
citrate-and phosphate-based emulsifying salts.

\begin{tabular}{|c|c|c|c|c|}
\hline Hydrocolloid & 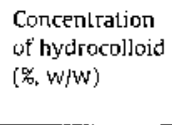 & $\begin{array}{l}\text { Additional } \\
\text { substances }\end{array}$ & $\begin{array}{l}\text { Concentration } \\
\text { of additional } \\
\text { substances } \\
{[\%, w / w)^{3}}\end{array}$ & Code \\
\hline \multirow{9}{*}{$\begin{array}{l}\text { Low methoxyl } \\
\text { peatin }\end{array}$} & 0.10 & None & & IECO \\
\hline & 0.10 & Lecithin & 0.2 & LECO.2 \\
\hline & 0.10 & Lecithin & 0.4 & LECO.4 \\
\hline & 0.10 & Lecithin & 0.6 & LECO.G \\
\hline & 0.10 & Lecithin & 0.8 & LECO.g \\
\hline & 0.10 & Lecithin & 1.0 & LEC1,0 \\
\hline & 0.15 & Nolue & & \\
\hline & 0.20 & Wonte & & \\
\hline & 0.25 & None & & \\
\hline \multirow[t]{4}{*}{ Locusi bean gum } & 0.20 & None & & \\
\hline & 0.40 & None & & \\
\hline & 0.60 & None & & \\
\hline & 0.80 & Wone & & \\
\hline \multirow[t]{5}{*}{ Modilied starclı } & 0.10 & None & & \\
\hline & 0.25 & None & & \\
\hline & 0.50 & None & & \\
\hline & 0.75 & Noluc & & \\
\hline & 1.00 & None & & \\
\hline \multirow[t]{8}{*}{ K-Carragcenan } & 0.10 & None & & $\mathrm{KCO} 0.1$ \\
\hline & 0.20 & Nore & & $\llbracket<0,2$ \\
\hline & 0.30 & None & & KCo.3 \\
\hline & 0.40 & None & & $\operatorname{kCO} 4$ \\
\hline & 0.50 & None & & KCO.5 \\
\hline & 0.60 & None & & KCO.E \\
\hline & 0.80 & None & & $\mathrm{kCO} .8$ \\
\hline & 1.00 & None & & $\mathrm{KC1.0}$ \\
\hline \multirow[t]{4}{*}{ 1-Carsagecnas] } & 0.10 & Moné & & $\operatorname{Ic0}, 1$ \\
\hline & 0.30 & None & & IC0.3. \\
\hline & 0.50 & None & & [CD. 5 \\
\hline & 1.00 & None & & IC 1.0 \\
\hline k-Carrageestan & 1.00 & Eunulsifying sa]ts & 2.0 & EAKC $^{\mathrm{a}}$ \\
\hline Wone & & Enulsifyriug salts & 2.0 & Contro] \\
\hline
\end{tabular}

a The sample with both "-carrageenan and emulsifying salts was used during the cooling study only.

during the cooling period of the sample by means of dynamic oscillatory rheometry.

The control samples with $2.0 \%, \mathrm{w} / \mathrm{w}$ (calculated from the total weight of Edam cheese, butter and water), of commercial emulsifying salts (sodium phosphate and polyphosphate salts - JOHA HBS, JOHA S9S and JOHA S4SS in a ratio of 1:4:1; Benckiser-Knapsack, Ladenburg, Germany) were also produced for all fat-in-dry matter contents tested.

\subsection{Production of processed cheeses}

Model processed cheeses with $40 \%(\mathrm{w} / \mathrm{w})$ dry matter and 45,50 or $55 \%$ $(\mathrm{w} / \mathrm{w})$ fat-in-dry matter were manufactured using a Vor-werk Thermomix TM 31-1 blender cooker (Vorwerk \& Co., GmbH, Wuppertal, Germany). A similar device for the production of processed cheeses was used by Černiková et al. (2008) and Lee, Anema, and Klostermeyer (2004). For the production of processed cheeses, the following ingredients were used: a block of Edam cheese $(30 \%, \mathrm{w} / \mathrm{w}$, fat-in-dry matter; $50 \%$, w/w, dry matter; 8 weeks maturity), butter $(82 \%, w / w$, fat; $84 \%, w / w$, dry matter), deionized water and emulsifying salts $(2.0 \%, \mathrm{w} / \mathrm{w})$ or hydrocolloids (in powder form) and emulsifier (lecithin). Edam cheese (400 g) was used for all types of processed cheese (regardless of the fat-in-dry matter content); 81,115 or $160 \mathrm{~g}$ of butter and 205,240 or $300 \mathrm{~g}$ of deionized water were used for the manufacture of all samples, with 
45, 50 and $55 \%$ fat-in-dry matter, respectively. The fat content of samples was confirmed using the acidobutyric method of van Gulik (ISO 3433, 2008).

Natural cheese and butter were cut into pieces (approximately $2 \times 2 \times 2 \mathrm{~cm}$ ), put into a melting pot and mechanically comminuted for 1 min. Most of the deionized water, hydrocolloids (in powder form; sometimes combined with an emulsifier where indicated) or powdered emulsifying salts (only in case of the control samples) were added separately. Finally, the remaining amount of deionized water was added. After the addition of all ingredients (about $2 \mathrm{~min}$ ), the speed range of the mixer was set at $4000 \mathrm{rpm}$. Samples were processed at a melting temperature of $90{ }^{\circ} \mathrm{C}$ for $1 \mathrm{~min}$ (the total processing time ranged between 10 and $12 \mathrm{~min}$ ). The samples were subsequently poured into polystyrene cups with sealable lids. Samples were then cooled down and stored at a temperature of $6 \pm 2{ }^{\circ} \mathrm{C}$. Analyses were carried out after 14 days of storage. All sample types were produced at least three times using the same protocol.

The samples were analysed for $\mathrm{pH}$ (pH-meter Gryf $208 \mathrm{~L}$ with glass electrode THETA 90 HC 113; Gryf, Havlíčkův Brod, Czech Republic) and dry matter content (ISO 5534, 2004). Compositional analyses were carried out in triplicate.

\subsection{Image analysis}

Samples were frozen at $-30 \pm 1{ }^{\circ} \mathrm{C}$ using a Microm HM 550 freezing microtome (Microm International $\mathrm{GmbH}$, Walldorf, Germany). After freezing, a block (1.0-1.2 cm high, $1.6-1.8 \mathrm{~cm}$ wide and $1.6-1.8 \mathrm{~cm}$ deep) was cut out from the middle of each product. The sections $(1.0-1.2 \mathrm{~cm}$ high, $1.6-1.8 \mathrm{~cm}$ wide and 7 (im thick) were subsequently sliced using the microtome. The slices were attached to microscopic slides and, after drying $\left(12 \mathrm{~h}\right.$ at a laboratory temperature of $\left.23 \pm 2{ }^{\circ} \mathrm{C}\right)$, were stained with Oil red to highlight the fat globules. The stained mounts were subsequently fixed in a glycerol-gelatine solution $(7 \mathrm{~g}$ of gelatine, $50 \mathrm{~g}$ of glycerol, $0.5 \mathrm{~g}$ of phenol and $40 \mathrm{~g}$ of distilled water) and dried for at least $5 \mathrm{~h}$ at a laboratory temperature of $23 \pm 2{ }^{\circ} \mathrm{C}$ (Flint, 1994). Under the light microscope, each slice of the product was optically sectioned (without physical separation) evenly into five layers (from the lid to the bottom of the cup; five layers were taken from a single frozen sample). The distance between the adjacent layers tested was $0.15-0.20 \mathrm{~cm}$. The layer nearest to the lid was referred to as layer 1 and the layer nearest to the bottom of the cup was referred to as layer 5 (in between were layers 2, 3 and 4). Within each layer, 15 photographs (from three replicates) of $2 \mathrm{~mm}^{2}$ area were analysed. For the purpose of the actual image analysis, the following conditions were used: a Nicon Eclipse 2000 microscope (magnification $125 \mathrm{x}$; Nicon, Tokyo, Japan), Canon PowerShot A620 camera (Canon, Tokyo, Japan) with scanning software PSRemote version 1.5.2. (Breeze Systems Limited, Bagshot, UK) and image analysis software, ACC scientific image analyzer, version 6.0 (Sofo, Brno, Czech Republic). The individual layers from each sample were analysed to determine the number and average size (area) of fat globules within the area analysed $\left(2 \mathrm{~mm}^{2}\right)$. The software only detected globules within the size range of $10-50,000 \backslash \mathrm{im}^{2}$ (the thresholds of measurement). The procedure of sample preparation was designed and verified by Tremlová, Štarha, Buñka, Gistingrová, and Hrabě (2006).

\subsection{Dynamic oscillatory rheometry}

Dynamic oscillatory rheometry was carried out using a Bohlin Gemini machine (Malvern Instruments Ltd., Malvern, $\mathrm{UI}<$ ), with a parallel plate geometry of diameter $40 \mathrm{~mm}$ and a gap of $1 \mathrm{~mm}$. The measuring temperature was set for $20.0 \pm 0.1^{\circ} \mathrm{C}$. All measurements were made within the region of linear viscoelasticity with a shear stress amplitude of $20 \mathrm{~Pa}$, and a frequency ranging from 0.1 to $50.0 \mathrm{~Hz}$. Two layers of each sample were analysed - the upper and the lower layer. The layers corresponded approximately to the 1st layer (upper) and 5th layer (lower) as referred to above. The thickness of each layer was $1 \mathrm{~mm}$. The control samples were spread into the geometry; the treatment samples were accurately cut out from the block (from the appropriate layer using the slicer and borer) and moved into the rheometer geometry. The storage $\left(\mathrm{G}^{7}\right)$ and loss $\left(\mathrm{G}^{7 /}\right)$ moduli were measured, and the complex shear modulus $\left(G^{*}\right)$ was calculated according to the formula:

$$
G^{*}=\sqrt{\left(G^{\prime}\right)^{2}+\left(G^{\prime}\right)^{2}}
$$

For the cooling experiments, a concentric cylinder geometry (bob in cup) was chosen with an inner cylinder diameter of $14 \mathrm{~mm}$, gap $0.7 \mathrm{~mm}$, oscillation frequency $1 \mathrm{~Hz}$ and amplitude of shear stress $20 \mathrm{~Pa}$. Immediately after processing, the sample was poured into the apparatus, pre-heated to $85{ }^{\circ} \mathrm{C}$. The sample was cooled from $80{ }^{\circ} \mathrm{C}$ to $10{ }^{\circ} \mathrm{C}$ at a cooling rate of $1{ }^{\circ} \mathrm{C} \mathrm{min}^{-1}$, and the storage ( $\left.\mathrm{G}^{\prime}\right)$ and loss (G") moduli were measured. All samples were measured at least four times (each type of sample was produced three times and each replicate were measured at least four times - a total of at least 12 analyses).

\subsection{Sensory analysis}

The sensory analysis was carried out by a panel of five expert assessors (employees of the Department of Food Technology and Microbiology, Tomas Bata University), extensively trained in describing processed cheese products according to ISO 8586-2 (2008). The products were evaluated using the following criteria: homogeneity (using 7-point scale: 1 - a completely homogeneous sample; 4 - slight inhomogeneity, acceptable; 7 - a completely inhomogeneous sample) and hardness (using 7-point scale: 1 - a very hard sample, impossible to spread; 4 - a sample showing typical qualities of processed cheese spread; 7 - a very soft/rather mushy sample). Fat release from the cheese was assessed by the panel during the homogeneity test. The sample, where the fat release was obvious, was not assessed as being homogeneous. Prior to the main testing sessions, training sessions with samples (both laboratory made products and market samples) were carried out with two aims: to define and describe different levels of the evaluated attributes (hardness and homogeneity) and to familiarise the assessors with the samples and the methodology of the testing procedures. Hardness was evaluated by spreading with a knife. The samples were assessed in a sensory laboratory equipped with sensory booths (under normal light condition) in accordance with ISO 8589 (1988). The processed cheese samples were tested after 14 days of storage at $6 \pm 2{ }^{\circ} \mathrm{C}$. The samples $(100 \mathrm{~g})$ were presented in randomized order (four-digit codes) on white plates (each sample on a separate plate) and were served at room temperature $(22 \pm 2$ $\left.{ }^{\circ} \mathrm{C}\right)$. Independent results of each assessor were evaluated and the median value reported.

\subsection{Data analysis}

The results of image analysis were evaluated by a Mann- Whitney test using Unistat version 5.5 software (Unistat Ltd., London, UK). The results of dynamic oscillatory rheometry were processed by Microcal Origin version 5.0 software (Microcal, Inc., Northampton, MA, USA). 


\section{Results and discussion}

\subsection{Screening of hydrocolloids}

The first stage of the experiment was designed to select hydrocolloids which enable the production of processed cheeses or their analogs without the use of phosphate- and citrate-based emulsifying salts. The control samples with $40 \%(\mathrm{w} / \mathrm{w})$ dry matter and all three variations of fat-in-dry matter content $(45,50$ or $55 \%, w / w)$ were homogeneous and easy to spread. The pH-values and dry matter contents of control samples were in the range of 5.74- 5.81 and $40.82-41.54 \%$ (w/w), respectively. The hardness of samples increased with the decreasing amount of fat-in-dry matter $(\mathrm{P}<0.05)$. This finding is in accordance with results of Dimitreli and Thomareis (2008).

The processing of cheese without traditional emulsifying salts containing locust bean gum, modified starch or low methoxyl pectin (concentrations $>0.15 \%$ ) was not feasible under the conditions tested (regardless of fat-in-dry matter content). During the manufacture of the samples, with either of these three hydrocolloids, we obtained two phases - tough matter on the bottom of cooker, and liquid matter. The following hydrocolloid combinations were evaluated as feasible: low methoxyl pectin combined with lecithin (samples with $40 \%$, w/w, dry matter and $45 \%$, w/w, fat-in- dry matter) and both carrageenans (samples with $40 \%, \mathrm{w} / \mathrm{w}$, dry matter and all tested fat-in-dry matter contents). The $\mathrm{pH}$ of samples with feasible combinations of hydrocolloids (in the range of $\mathrm{pH}$ 5.50-5.61) was lower in comparison with the control samples $(\mathrm{P}<0.05)$. Dry matter content of feasible samples was similar $(\mathrm{P}$ $>0.05$; data not shown) compared with the control samples.

Therefore, the products with (i) $0.10 \%(\mathrm{w} / \mathrm{w})$ low methoxyl pectin and $0.0,0.2,0.4,0.6,0.8$ or $1.0 \%(\mathrm{w} / \mathrm{w})$ lecithin; and (ii) $0.1-1.0 \%(\mathrm{w} / \mathrm{w}) \mathrm{k}-$ or i-carrageenans $(55 \%, \mathrm{w} / \mathrm{w}$, fat-in-dry matter content was chosen only; samples with carrageenans are listed in Table 2) were tested by means of sensory analysis, image analysis of micrographs and dynamic oscillatory rheometry. The samples were evaluated after 14 days of storage at $6 \pm 2$ ${ }^{\circ} \mathrm{C}$. The evaluation of product homogeneity was based on the assumption that the whole mass of the product is homogeneous if each layer of the product has: (i) approximately the same number of fat globules, (ii) the fat globules take up approximately the same area, and (iii) the individual layers show similar viscoelastic properties. The results of image analysis of the second experiment are presented in Tables 3 and 4 . The results of dynamic oscillatory rheometry are shown graphically (Fig. 1).

According to Tables 3 and 4 , the control samples had a similar number of fat globules $(\mathrm{P}>0.05)$ with a similar average area (size) $(\mathrm{P}>$ 0.05) within the five layers tested. Both the first and fifth layers, analysed by means of dynamic oscillatory rheometry, reached similar values of the complex shear modulus $\left(\mathrm{G}^{*}\right)$ within the whole frequency range tested (0.1-50.0 Hz; data not shown). On the basis of these results, the control samples were considered to be homogeneous, which was also confirmed by the sensory analysis.

From the sensoiy point of view, the processed cheeses with $40 \%$ $(\mathrm{w} / \mathrm{w})$ dry matter and $45 \%(\mathrm{w} / \mathrm{w})$ fat-in-dry matter with $0.10 \%(\mathrm{w} / \mathrm{w})$ low methoxyl pectin and $0.0-0.8 \%(\mathrm{w} / \mathrm{w})$ lecithin content were evaluated as inhomogeneous. This evaluation was confirmed by the image analysis of fat globules (Tables 3 and 4). Sensory evaluation of the products with $0.10 \%(\mathrm{w} / \mathrm{w})$ low methoxyl pectin and $1.0 \%(\mathrm{w} / \mathrm{w})$ lecithin showed that the product with $1.0 \%(\mathrm{w} / \mathrm{w})$ lecithin can be considered macroscopically (sensorially) homogeneous without the obvious release of fat. However, the first layer (closest to the lid of the cup) of this sample contained fat globules of larger size $(\mathrm{P}<0.01)$ compared with the other layers (Table 4).
Table 2

Results of sensory evaluation of homogeneity and hardness of the samples $(40 \%, \mathrm{w} / \mathrm{w}$, dry matter content and $55 \%, \mathrm{w} / \mathrm{w}$, fat-in-dry matter content) processed without emulsifying salts and with K- or i-carrageenan (expressed as median; $\mathrm{n}=5$ ).

\begin{tabular}{|c|c|c|c|}
\hline \multirow[t]{2}{*}{ Hydrocolloid } & \multirow{2}{*}{$\begin{array}{l}\text { Concentration of } \\
\text { hydrocolloid }(\mathrm{K}, \mathrm{w} / \mathrm{w})\end{array}$} & \multicolumn{2}{|c|}{ Sensory evaluation } \\
\hline & & Homogeneity ${ }^{\mathrm{a}}$ & $\mathrm{H}_{\mathrm{s}}$ rdness \\
\hline \multirow[t]{8}{*}{ к-Carrageепап } & 0.10 & 5 & 4 \\
\hline & 020 & 4 & 3 \\
\hline & 0.30 & 4 & 3 \\
\hline & 0.40 & 3 & 2 \\
\hline & 0.50 & 1 & 2 \\
\hline & 0,60 & 1 & 1 \\
\hline & 0.80 & 1 & 1 \\
\hline & 1.00 & 1 & 1 \\
\hline \multirow{4}{*}{ l-Carrageenan } & 0.10 & 5 & 3 \\
\hline & 0.30 & 4 & 2 \\
\hline & 0.50 & 1 & 1 \\
\hline & 1,00 & 1 & 1 \\
\hline Nonec & & 1 & 5 \\
\hline
\end{tabular}

a Homogeneity: 1 - completely homogeneous sample, 4 - slight inhomogeneity, acceptable, 7 - a completely inhomogeneous sample.

${ }^{\mathrm{b}}$ Hardness: 1 - very hard, 7 - very soft.

c Control sample $(40 \%, w / w$, dry matter content and $55 \%$, w/w, fat-in-dry matter content) with $2 \%(\mathrm{w} / \mathrm{w})$ emulsifying salts.

For samples with $0.10 \%(\mathrm{w} / \mathrm{w})$ low methoxyl pectin (with and without lecithin) the upper layer has a significantly lower complex shear modulus $\left(G^{*}\right)$ compared with the lower layer (Fig. 1A). A similar difference in the upper and lower layers was also detected in the other samples (with 0.2$0.8 \%, w / w$, lecithin; data not shown). On the basis of the results of dynamic oscillatory rheometry and image analysis of the micrographs, the samples with low methoxyl pectin were considered inhomogeneous.

From the sensory point of view (Table 2), the processed cheeses with $40 \%(\mathrm{w} / \mathrm{w})$ dry matter and $55 \%(\mathrm{w} / \mathrm{w})$ fat-in-dry matter with $0.1-0.4 \%$ $(\mathrm{w} / \mathrm{w}) \mathrm{K}$-carrageenan and $0.1-0.3 \%(\mathrm{w} / \mathrm{w})$ i-carrageenan were evaluated as slightly inhomogeneous, with a more fluid upper layer subtly separated from a thicker lower layer. From the image analysis data, it was found (Table 3) that the upper layer of most of above-mentioned samples contained a smaller number of fat globules in comparison with the lower layers. The average size (area) of fat globules in most of these samples was less in the lower layers compared with the upper layers (Table 4). From the dynamic oscillatory rheometry data (Fig. IB and C), it was found that the upper layer of these samples (with the exception of the sample containing $1.0 \%, \mathrm{w} / \mathrm{w}$, i-carrageenan) showed lower values for the complex shear modulus $\left(\mathrm{G}^{*}\right)$ in comparison with the lower layer. The products with $0.5-1.0 \% \quad(\mathrm{w} / \mathrm{w})$ carrageenans were evaluated macroscopically (sensorially) as homogeneous without obvious release of fat. However, in the samples with less than $1.0 \%(\mathrm{w} / \mathrm{w})$ carrageenans, the image analysis of fat globules and dynamic oscillatory rheometry revealed a different number and size of fat globules $(\mathrm{P}>0.01)$ and different values of the complex shear modulus (with the exception of the sample containing $0.5 \%(\mathrm{w} / \mathrm{w})$ ic-carrageenan) in the individual layers (Tables 3 and 4 ; Fig. 1B-D).

Only in the sample with $1.0 \%(\mathrm{w} / \mathrm{w})$ ic-carrageenan were the number of fat globules and their sizes similar $(\mathrm{P}>0.01)$ in all five layers analysed (Tables 3 and 4). The dynamic oscillatory rheometry showed that the complex shear modulus $\left(\mathrm{G}^{*}\right)$ was practically the same in both upper and lower layers (Fig. ID). In the case of $1.0 \%$ (w/w) i-carrageenan, the number of fat globules in the individual layers was insignificantly different $(\mathrm{P}>0.01)$. The complex shear modulus $\left(\mathrm{G}^{*}\right)$ was similar for the upper and lower layers (Fig. IB), however, significant differences ( $\mathrm{P}<$ 0.01) were detected in the average size of the fat globules within the layers analysed (Table 4), although there was no difference between the upper and 
Table 3

The number of fat globules in the layers of samples (with $40 \%, \mathrm{w} / \mathrm{w}$, dry matter content) with the addition of $0.1 \%$ (w/w) low methoxyl pectin combined with lecithin (samples with $45 \%$, $\mathrm{w} / \mathrm{w}$, fat-in-dry matter content) or with the addition of K-carrageenan or i-carrageenan (samples with $55 \%$, w/w, fat-in-dry matter content). ${ }^{3}$

\begin{tabular}{|c|c|c|c|c|c|c|}
\hline \multirow[t]{2}{*}{ Fat-in-dry matter $\left[w_{1}, w / w\right)$} & \multirow[t]{2}{*}{ Sanple } & \multicolumn{5}{|l|}{ Layber } \\
\hline & & 1 & 2 & 3 & 4 & 5 \\
\hline 45 & $\begin{array}{l}\text { Contral } \\
\text { LECO } \\
\text { LECO.2 } \\
\text { LECO } 4 \\
\text { LECO.E } \\
\text { LECO.8 } \\
\text { LEC1.0 }\end{array}$ & $\begin{array}{l}522 \pm 100^{3} \\
853 \pm 85^{4} \\
821 \pm 75^{a} \\
721 \pm 105^{\mathrm{a}} \mathrm{b} \\
700 \pm 39^{\mathrm{a}} \\
645 \pm 41^{\mathrm{a}} \\
377 \pm 23^{\mathrm{a}}\end{array}$ & $\begin{array}{l}465=59^{\mathrm{a}} \\
742.74^{\circ} \\
799=32^{\mathrm{a}} \\
657=50^{\mathrm{a}} \\
748=28^{1} \\
728 \pm 40^{d} \\
374=28^{a}\end{array}$ & $\begin{array}{l}452 \pm 29^{a} \\
569 \pm 79^{c} \\
651 \pm 26^{\mathrm{b}} \\
836 \pm 55^{2} \\
755+28^{\mathrm{a}} \\
723 \leq 40^{\mathrm{a}} \\
434 \pm 30^{\mathrm{a}}\end{array}$ & $\begin{array}{l}426 \pm 52^{a} \\
50 \mathrm{I} \pm 60^{c} \\
549 \pm 34^{c} \\
759 \pm 32^{\mathrm{b}} \\
895+47^{\mathrm{b}} \\
672 \neq 30^{\mathrm{a}} \\
440 \pm 27^{\mathrm{a}}\end{array}$ & $\begin{array}{l}572 \pm 57^{\mathrm{a}} \\
424 \pm 65^{\mathrm{c}} \\
586 \pm 51^{\mathrm{c}} \\
692 \pm 38^{\mathrm{d}} \\
1038 \pm 69^{\mathrm{c}} \\
846 \pm 67^{\mathrm{b}} \\
507 \pm 43^{\mathrm{a}}\end{array}$ \\
\hline 55 & $\begin{array}{l}\text { Control } \\
k C 0.1 \\
k C 0.2 \\
k C 0.3 \\
k C 0.4 \\
k C 0.5 \\
k C 0.5 \\
k C 0.8 \\
k C 1.0 \\
I C 0.1 \\
I C 0.3 \\
I C 0.5 \\
I C 1.0\end{array}$ & $\begin{array}{l}1251=85^{\mathrm{a}} \\
2008=191^{\mathrm{n}, \mathrm{b},} \\
842 \pm 106^{\mathrm{a}} \\
891 \pm 45^{\mathrm{a}} \\
851=37^{\mathrm{a}} \\
934 \pm 36^{\mathrm{a}} \\
994=40^{\mathrm{a}} \\
1063 \pm 44^{\mathrm{a}} \\
1258 \pm 58^{\circ} \\
601=60^{+} \\
801=73^{\prime \prime} \\
1349 \pm 138^{\mathrm{a}} \\
1080 \pm 46^{+}\end{array}$ & $\begin{array}{l}1148+53^{\mathrm{a}} \\
2362=173^{\mathrm{b}} \\
1067=125^{\mathrm{a}} \\
1072=59^{\mathrm{a} b} \\
1249=43^{\mathrm{b}} \\
1106 \pm 45^{\mathrm{b}, c} \\
1167=33^{\mathrm{b}, c} \\
1333=45^{\mathrm{b}} \\
1389=40^{\mathrm{a}} \\
1147: 59^{\mathrm{b}} \\
1129: 80^{\mathrm{b}} \\
1137 \pm 131^{\mathrm{a}, \mathrm{b}} \\
1197:=35^{\mathrm{d}}\end{array}$ & $\begin{array}{l}1191 \pm 75^{\mathrm{a}} \\
2186 \pm 187^{\mathrm{a}, \mathrm{b}} \\
1230 \pm 133^{\mathrm{a}, \mathrm{b}} \\
1170 \pm 54^{\mathrm{b}} \\
1457 \pm 62^{\mathrm{b}} \\
1250 \pm 42^{\mathrm{b}} \\
1283 \pm 45^{\mathrm{b}} \\
1447 \pm 38^{\mathrm{b}} \\
1402: 51^{\mathrm{a}} \\
1141.47^{\mathrm{b}} \\
1198+52^{\mathrm{b}} \\
90 \mathrm{t}+113^{\mathrm{a}} \mathrm{b} \\
1250+64^{\mathrm{a}}\end{array}$ & $\begin{array}{l}1250 \pm 53^{\mathrm{a}} \\
1503 \pm 150^{\mathrm{c}} \\
1293 \pm 174^{2 . b} \\
1147 \pm 61^{\mathrm{h}} \\
1446 \pm 69^{\mathrm{h}} \\
1171+32^{\mathrm{b}-\mathrm{c}} \\
1178 \pm 37^{\mathrm{b}-\mathrm{c}} \\
1402 \pm 47^{\mathrm{b}} \\
1408+46^{\mathrm{d}} \\
1182 \pm 47^{\mathrm{b}} \\
1220 \pm 53^{\mathrm{b}} \\
850 \pm 56^{\mathrm{b}} \\
1192+37^{\mathrm{a}}\end{array}$ & $\begin{array}{l}1367=85^{\mathrm{a}} \\
1652=175^{\mathrm{a}} \\
1705=177^{\mathrm{h}} \\
1018 \pm 60^{\mathrm{d}} \\
1050 \pm 49^{\mathrm{b}} \\
1062 \pm 48^{\mathrm{d}, \mathrm{c}} \\
106]: 36^{\mathrm{a}, \mathrm{c}} \\
1317 \pm 161^{\mathrm{b}} \\
1373 \pm 61^{\mathrm{d}} \\
869 \pm 66^{\mathrm{a}} \\
1173 \pm 56^{\mathrm{b}} \\
825 \pm 46^{\mathrm{b}} \\
1155 \pm 36^{\mathrm{a}}\end{array}$ \\
\hline
\end{tabular}

a The number of fat globules is expressed as mean \pm standard error $(\mathrm{n}=15)$. Means with the same superscript letter in each row are not significantly different $(\mathrm{P}>0.01)$. ${ }^{\mathrm{b}}$ The sample codes are explained in Table 1 .

${ }^{c} 1$ st layer corresponds to the upper layer and the 5 th layer corresponds to the lower layer.

lower layers. Samples with added carrageenans were evaluated as significantly harder $(\mathrm{P}<0.05)$ compared with the control sample with the same fat-in-dry matter content (Table 2).

Locust bean gum and modified starch could not be used as full substitutes for traditional emulsifying salts. This finding differs from the work of Pluta, Ziarno, and Smolinska (2000), who described these hydrocolloids as a possible substitute. However, during a detailed study of their work it was discovered that a small amount of phosphate emulsifying salts was included in their ingredients. Thus, it was only a partial substitute for traditional emulsifying salts. Low methoxyl pectin enabled the production of processed cheeses without the application of phosphate or citrate emulsifying salts but the final product appeared to be inhomoge- neous. In the upper layers there were larger amounts of fat in comparison with the lower layers. An increasing amount of fat in processed cheese decreases the rigidity of the system due to the interruption of the continuity of the protein matrix (Raval \& Mistry, 1999). Moreover, the inhomogeneity remained unchanged after the addition of lecithin emulsifier (Tables 3 and 4). It follows that even low methoxyl pectin in combination with lecithin does not provide a suitable substitute for traditional emulsifying salts. Low methoxyl pectin, locust bean gum and modified starch probably do not have sufficient emulsifying ability (Bao, Xing, Phillips, \& Corke, 2003; Leroux, Langendorff, Schick, Vaishnav, \& Mazoyer, 2003; Phillips \&

Table 4

Average area of a fat globule $\left(\mathrm{jim}^{2}\right.$ ) in the layers of samples (dry matter content $40 \% \mathrm{w} / \mathrm{w}$ ) with the addition of $0.1 \%$ (w/w) low methoxyl pectin combined with lecithin (samples with $45 \%$, $\mathrm{w} / \mathrm{w}$, fat-in-dry matter content) or with the addition of K-carrageenan or i-carrageenan (samples with $55 \%$, w/w, fat-in-dry matter content). ${ }^{3}$

\begin{tabular}{|c|c|c|c|c|c|c|}
\hline \multirow[t]{2}{*}{ Fal-in-dry matter $\left(\alpha_{w} w / w\right)$} & \multirow[t]{2}{*}{ Sample } & \multicolumn{5}{|l|}{ Layer' } \\
\hline & & 1 & 2 & 3 & 4 & 5 \\
\hline 45 & $\begin{array}{l}\text { Contral } \\
\text { LECO } \\
\text { LECO.2 } \\
\text { LECO.4 } \\
\text { LECO.6 } \\
\text { LECO.8 } \\
\text { LEC } 1.0\end{array}$ & $\begin{array}{c}65: 2^{\mathrm{a}} \\
521: 84^{\mathrm{a}} \\
525 \pm 20^{\mathrm{a}} \\
441 \pm 64^{\mathrm{a}} \\
462 \pm 13^{\mathrm{a}} \\
371 \pm 12^{\mathrm{a}} \\
468 \pm 16^{\mathrm{a}}\end{array}$ & $\begin{array}{l}54 \pm 2^{\mathrm{a}} \\
308 \pm 52^{\mathrm{b}} \\
207 \pm 7^{\mathrm{b}} \\
531 \pm 19^{\mathrm{b}} \\
364 \pm 10^{\mathrm{b}} \\
278 \pm 8^{\mathrm{b}} \\
290 \pm 10^{\mathrm{b}}\end{array}$ & $\begin{array}{l}55 \pm 2^{\mathrm{a}} \\
107 \pm 22^{\mathrm{c}} \\
150 \pm 5^{\mathrm{b}, \mathrm{c}} \\
393 \pm 16^{\mathrm{d}} \\
303 \pm 7^{\mathrm{c}} \\
267 \pm 7^{\mathrm{b}} \\
267 \pm 8^{\mathrm{b}}\end{array}$ & $\begin{array}{l}59 \pm 2^{\mathrm{j}} \\
94 \pm 15^{c} \\
124 \pm 3^{\mathrm{c}} \\
314 \pm 8^{\mathrm{c}} \\
179 \pm 4^{\mathrm{d}} \\
246 \pm 7^{\mathrm{b}} \\
211 \pm 6^{\mathrm{c}}\end{array}$ & $\begin{array}{l}64 \pm 2^{\prime} \\
115 \pm 24^{\mathrm{C}} \\
114+2^{\mathrm{C}} \\
200+4^{\mathrm{d}} \\
141 \pm 2^{\mathrm{C}} \\
136 \pm 2^{\mathrm{C}} \\
107 \pm 2^{\mathrm{d}}\end{array}$ \\
\hline 55 & $\begin{array}{l}\text { Control } \\
\mathrm{KCO} .1 \\
\mathrm{KCO} .2 \\
\mathrm{KCO} .3 \\
\mathrm{KCO} .4 \\
\mathrm{KCO} 0.5 \\
\mathrm{KCO} .6 \\
\mathrm{KCO} .8 \\
\mathrm{KCO} 1.0 \\
\mathrm{ICO} .1 \\
\mathrm{JCO} .3 \\
\mathrm{ICO} .5 \\
\mathrm{ICO} 1.0\end{array}$ & $\begin{array}{l}264 \pm 26^{a} \\
151 \pm 12^{\prime} \\
329 \pm 38^{d} \\
359 \pm 25^{-1} \\
277 \pm 19^{-1} \\
368 \pm 25^{\circ} \\
357 \pm 28^{-1} \\
413 \pm 33^{\circ} \\
249 \pm 20^{A} \\
398 \pm 35^{\circ} \\
535 \pm 52^{A} \\
388 \pm 18^{\circ} \\
131 \pm 7^{d}\end{array}$ & $\begin{array}{l}270 \pm 21^{\mathrm{a}} \\
193=21^{\mathrm{a}} \\
289: 126^{\mathrm{a}} \\
298 \pm 30^{\mathrm{a}, \mathrm{b}} \\
148=10^{\mathrm{b}} \\
305 \pm 15^{\mathrm{a}, \mathrm{b}} \\
291=22^{\mathrm{a}, \mathrm{b}} \\
328 \pm 26^{\mathrm{a}, \mathrm{b}} \\
215=9^{\mathrm{a}} \\
304 \pm 25^{\mathrm{a}} \\
375=45^{\mathrm{a}, \mathrm{b}} \\
345=13^{\mathrm{a} b} \\
119=8^{\mathrm{a}, \mathrm{b}}\end{array}$ & $\begin{array}{l}270 \pm 23^{\mathrm{a}} \\
185 \pm 10^{\mathrm{a}} \\
235 \pm 17^{\mathrm{a}} \\
245 \pm 22^{\mathrm{b}} \\
144 \pm 15^{\mathrm{b}} \\
274 \pm 14^{\mathrm{b}} \\
269 \pm 13^{\mathrm{b}} \\
260 \pm 21^{\mathrm{b}} \\
208 \pm 9^{-1} \\
365 \pm 32^{\mathrm{a}} \\
336 \pm 33^{\mathrm{b}, c} \\
308 \pm 15^{\mathrm{b}} \\
99 \pm 5^{\mathrm{b}}\end{array}$ & 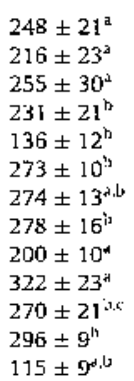 & 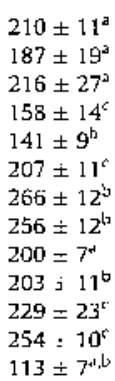 \\
\hline
\end{tabular}

a The area of fat globules is expressed as mean \pm standard error $(n=15)$. Means with the same superscript letter in each row are not significantly different $(\mathrm{P}>0.01)$. ${ }^{\mathrm{b}}$ The sample codes are explained in Table 1.

c 1 st layer corresponds to the upper layer and the 5 th layer corresponds to the lower layer. 


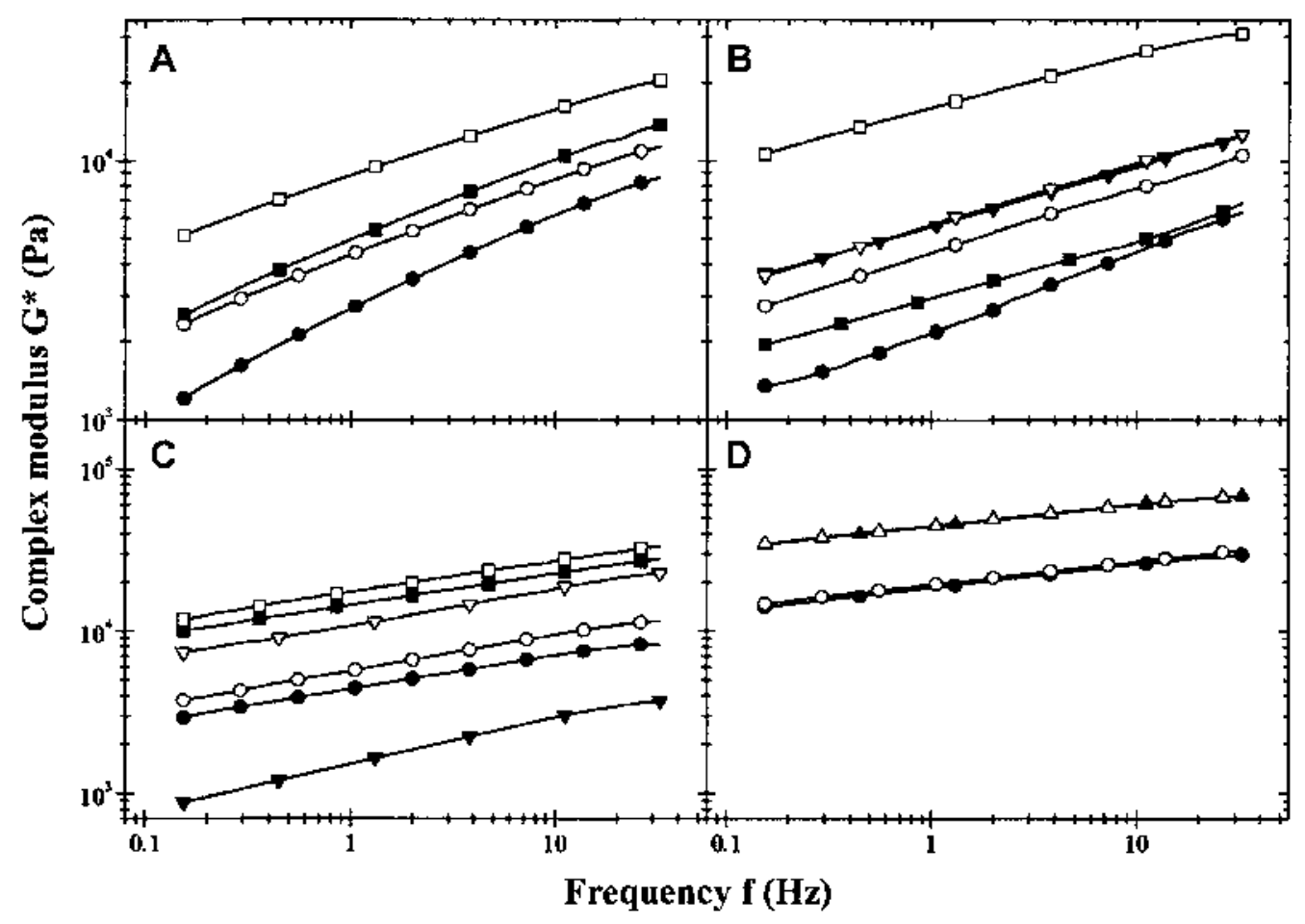

Fig. Dependence of the complex shear modulus $\left(\mathrm{G}^{*}\right)$ on frequency (/) for the samples without emulsifying salts and with the addition of hydrocolloids. (A) Samples with $40 \%$ (w/w) dry matter content and $45 \%(\mathrm{w} / \mathrm{w})$ fat-in-dry matter content; $0.1 \%(\mathrm{w} / \mathrm{w})$ pectin - upper layer $(\mathbf{( - )}) ; 0.1 \%(\mathrm{w} / \mathrm{w})$ pectin - lower layer $(\square) ; 0.1 \%(\mathrm{w} / \mathrm{w})$ pectin and $1.0 \%(\mathrm{w} / \mathrm{w})$ lecithin - upper layer $(\bullet) ; 0.1 \%(\mathrm{w} / \mathrm{w})$ pectin and $1.0 \%(\mathrm{w} / \mathrm{w})$ lecithin - lower layer (O). (B) Samples with $40 \%(\mathrm{w} / \mathrm{w})$ dry matter content and $55 \%(\mathrm{w} / \mathrm{w})$ fat-in-dry matter content; $0.1 \%(\mathrm{w} / \mathrm{w}) \mathrm{i}$-carrageenan - upper layer (-); $0.1 \%(\mathrm{w} / \mathrm{w}) \mathrm{i}-$ carrageenan - lower layer (ㅁ); $0.5 \%(\mathrm{w} / \mathrm{w}) \mathrm{t}$-carrageenan - upper layer $(\bullet) ; 0.5 \%(\mathrm{w} / \mathrm{w})$ i-carrageenan - lower layer (O); $1.0 \%(\mathrm{w} / \mathrm{w}) \mathrm{i}$-carrageenan - upper layer ( $\mathbf{V}) ; 1.0 \%(\mathrm{w} / \mathrm{w})$ i-carrageenan - lower layer (v). (C) Samples with $40 \%(w / w)$ dry matter content and 55\% (w/w) fat-in- dry matter content; $0.1 \%(w / w)$ K-carrageenan - upper layer ( $\mathbf{v}) ; 0.1 \%(w / w)$ ic-carrageenan - lower layer (V); $0.2 \%$

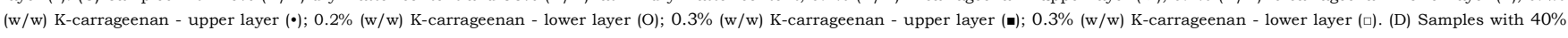
$(\mathrm{w} / \mathrm{w})$ dry matter content and $55 \%(\mathrm{w} / \mathrm{w})$ fat-in-dry matter content; 0.5\% (w/w) K-carrageenan - upper layer $(\cdot)$; $0.5 \%(\mathrm{w} / \mathrm{w}) \mathrm{K}-$ carrageenan - lower layer $(\mathrm{O}) ; 1.0 \%(\mathrm{w} / \mathrm{w}) \mathrm{K}-\mathrm{carrageenan}-\mathrm{upper}$ layer (A); $1.0 \%(\mathrm{w} / \mathrm{w}) \mathrm{K}$-carrageenan - lower layer (A).

Williams, 2000) to stabilise fat during the production of processed cheeses. On the other hand, $\mathrm{K}$ - and i-carrageenan appear to be potential substitutes for traditional emulsifying salts, mainly at a concentration of $1.0 \%$, at which both macroscopic and microscopic homogeneity of the final products was found by the methods used in this study. The ability of these components to stabilise the fat in processed cheese is probably connected with the ability to bind to hydrophobic parts of proteins (especially the casein fractions) in the presence of calcium ions (Lynch \& Mulvihill, 1996) and thus stabilise both water and fat (Dickinson, 2003; Doublier, Garnier, Renard, \& Sanchez, 2000; Ercelebi \& Ibanoglu, 2007; Hemar, Hall, Munro, \& Singh, 2002; Phillips \& Williams, 2000).

The products with $\mathrm{K}$ - and $\mathrm{i}$-carrageenan were assessed as very hard and impossible to spread. Increased hardness of the protein matrix in processed cheese after the application of both $\mathrm{K}$ - and i-carrageenan was also confirmed by Černíková et al. (2008) and Gustaw and Mleko (2007). Moreover, as Černíková et al. (2008) reported, K-carrageenan increased the hardness of the protein matrix in processed cheese to a lesser extent than i-carrageenan.

\subsection{Gel formation during the cooling period of processed cheese}

The process of gel formation during the cooling period was observed only with the sample which was considered to be homogeneous according to all analyses conducted in the first part of the experiment (control sample with $40 \%$, w/w, dry matter; $55 \%$, w/w, fat-in-dry matter with the application of $1.0 \%, \mathrm{w} / \mathrm{w}, \mathrm{K}$-carrageenan). Temperature dependence of the complex shear modulus $\left(G^{*}\right)$ is illustrated in Fig. 2. In the control sample, a slow and gradual increase in the values of complex shear modulus was noted during the cooling process. This increase was accelerated at a temperature of $15-10{ }^{\circ} \mathrm{C}$. The cooling process of the processed cheese without the use of traditional emulsifying salts (i.e., with $1.0 \%$, w/w, K-carrageenan; KC1.0) was completely different. Within the temperature range of $80-55^{\circ} \mathrm{C}$, the increase in the complex shear modulus $\left(\mathrm{G}^{*}\right)$ was also slow and gradual; the melt had a slightly lower $\mathrm{G}^{*}$ in comparison with the control sample. However, within the temperature range of $55-45^{\circ} \mathrm{C}$, a dramatic (100-fold) increase in the complex shear modulus $\left(\mathrm{G}^{*}\right)$ occurred. During the course of further cooling from $45{ }^{\circ} \mathrm{C}$ to $10{ }^{\circ} \mathrm{C}$, only a slow and gradual increase in $\mathrm{G}^{*}$ was observed. At a temperature of $15-10{ }^{\circ} \mathrm{C}$, the trend of an increase in the complex shear modulus $\left(\mathrm{G}^{*}\right)$ did not change as much as the control sample.

A higher complex shear modulus $\left(\mathrm{G}^{*}\right)$ was found for the sample containing emulsifying salts and $1.0 \%, \mathrm{w} / \mathrm{w}, \mathrm{K}$-carrageenan (EAKC) compared to the control sample during the cooling process. Within the temperature range of $80-55{ }^{\circ} \mathrm{C}$, a gradual increase in $\mathrm{G}^{*}$ was followed by a sharper rise in $\mathrm{G}^{*}$ during the transition from $55^{\circ} \mathrm{C}$ to $45^{\circ} \mathrm{C}$. However, this increase was not as large as that for the sample with $1.0 \%(\mathrm{w} / \mathrm{w}) \mathrm{K}-$ carrageenan without the addition of emulsifying salts. A further drop in temperature from 45 to $15{ }^{\circ} \mathrm{C}$ resulted in a smaller increase of $\mathrm{G}^{*}$. Within the temperature range of $15-10{ }^{\circ} \mathrm{C}$, a small increase in $\mathrm{G}^{*}$ was noted, similar to that of the control sample. The highest value of the complex shear modulus $\left(\mathrm{G}^{*}\right)$ at $10{ }^{\circ} \mathrm{C}$ was found for $\mathrm{KC} 1.0$ followed by EAKC and then the control sample. The same conclusion was also reached by means of the sensory analysis; the $\mathrm{KC} 1.0$ sample was found to be the hardest (so hard, that it was practically impossible to spread), followed by EAKC 


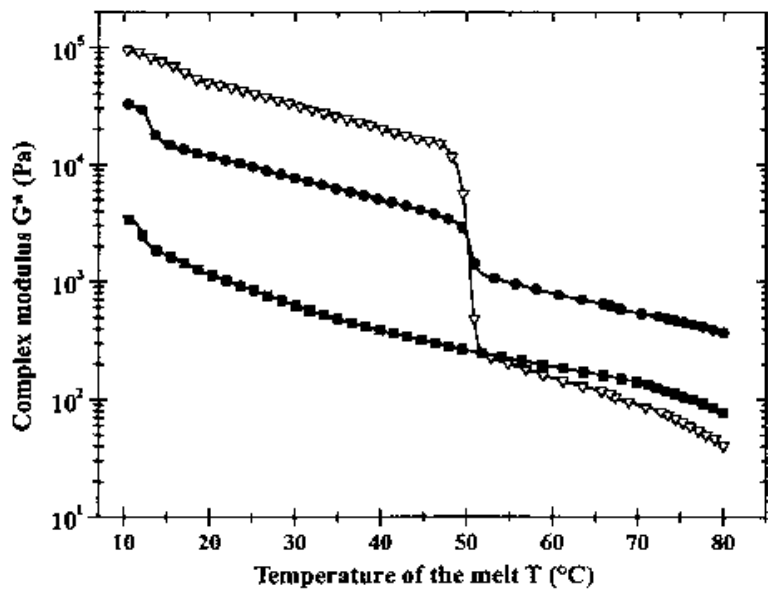

Fig. 2. Dependence of the complex shear modulus $\left(\mathbf{G}^{*}\right)$ on the falling temperature (T) in processed cheeses: control processed cheese with emulsifying salts and without $\mathrm{K}$ carrageenan (-); processed cheese without emulsifying salts and with $1.0 \%(\mathrm{w} / \mathrm{w}) \mathrm{K}-$ carrageenan (v); and processed cheese with emulsifying salts and 1.0\% (w/w) K-carrageenan ( $\cdot$ ).

(hard, possible to spread with difficulty) and the least hard control sample $(\mathrm{P}<0.05)$, which was easy to spread.

The image analysis of these samples was also carried out (data not shown). There was a similar number of fat globules $(P>0.01)$ with an insignificant difference in average area $(\mathrm{P}>0.01)$ in all three products and at all five layers analysed.

The increase in $\mathrm{G}^{*}$ within the temperature range of $55-45{ }^{\circ} \mathrm{C}$ probably corresponds to the transition of K-carrageenan from coil (disordered) to helix (ordered) state (Langendorff et al, 1999). This transition is a necessary condition for the production of a stable three-dimensional gel (Nickerson, Paulson, \& Hallett, 2004). The transition temperature of carrageenans depends on many factors, such as the ionic environment, type and concentration of carrageenans (Langendorff et al., 1999; Nickerson et al, 2004). The transition of K-carrageenan from disordered to ordered state and subsequent gelation of helical structures probably took place during the cooling process of the melt with $1.0 \% \mathrm{~K}$ carrageenan in the presence of emulsifying salts (Fig. 2).

\section{Conclusions}

Selected hydrocolloids in matrices with different fat-in-dry matter content $(45-55 \%, \mathrm{w} / \mathrm{w})$ were tested as possible replacements for phosphate- and citrate-based emulsifying salts in processed cheese production. Locust bean gum, modified starch (with bound sodium octenyl succinate) and low methoxyl pectin (alone and in combination with lecithin) cannot be recommended as replacements. On the other hand, $\mathrm{k-}$ and i-carrageenan appear to be suitable potential replacements for traditional emulsifying salts, however, the final products were very hard. Before they can be feasibly introduced into commercial production, it will be necessary to examine system stability, and decrease the hardness and improve spreadability. In addition, melting properties, oiling-off characteristics and texture profile analysis of samples, where traditional phosphate- and citrate-based emulsifying salts are replaced by carrageenans, should also be studied.

\section{Acknowledgment}

This work was kindly supported by a project of the Ministry of Education, Youth and Sports of the Czech Republic (Grant no. MSM6215712402).

\section{References}

Bao, J., Xing, J., Phillips, D., \& Corke, H. (2003). Physical properties of octenyl succinic anhydride modified, rice, wheat and potato starches. Journal of Agriculture and Food Chemistry, 51, 2283-2287.

Benichou, A., Aserin, A., 8 Garti, N. (2002). Protein-polysaccharide interactions for stabilization of food emulsions. Journal of Dispersion Science and Technology, 23, 93-123.

Buchman, A. L., \& Moukarzel, A. (2000). Metabolic bone disease associated with total parenteral nutrition. Clinical Nutrition, 19, 217-231.

Caric, M, \& Kaláb, M. (1997). Processed cheese products. In P. F. Fox, P. L. H. McSweeney, \& T. P. Cogan (Eds.), Cheese: Chemistry, physics and microbiology (2nd ed.).Major Cheese groups, Vol. 2 (pp. 467-505) London, UK: Elsevier Applied Science.

Cashman, K. D. (2006). Milk minerals (including trace elements) and bone health. International Dairy Journal, 16,1389-1398.

Černíková, M., Buňka, F., Pavlinek, V., Březina, P., Hrabě, J., \& Valášek, P. (2008). Effect of carrageenan type on viscoelastic properties of processed cheese. Food Hydrocolloids, 22,1054-1061.

Dickinson, E. (2003). Hydrocolloids at interfaces and the influence on the properties of dispersed systems. Food Hydrocolloids, 17, 25-39.

Dimitreli, G., \& Thomareis, A. S. (2008). Effect of chemical composition on the linear viscoelastic properties of spreadable-type processed cheese. Journal of Food Engineering, 84, 368-374.

Doublier, J. L., Gamier, C., Renard, D., \& Sanchez, C. (2000). Protein-polysaccharide interaction. Current Opinion in Colloid and Interface Science, 5, 202-214.

Ercelebi, E. A., \& Ibanoglu, E. (2007). Influence of hydrocolloids on phase separation and emulsion properties of whey protein isolate. Journal of Food Engineering, 80, 454459.

Flint, O. (1994). Food microscopy (1st ed.). Oxford, UK: Bios Scientific Publishers Limited.

Garti, N., \& Leser, M. E. (2001). Emulsification properties of hydrocolloids. Polymers for Advanced Technologies, 12,123-135.

Guinee, T. P., Carič, M., \& Kaláb, M. (2004). Pasteurized processed cheese and substitute/imitation cheese products. In P. F. Fox, P. L. H. McSweeney, T. P. Cogan, $\&$ T. P. Guinee (Eds.), Cheese: Chemistry, physics and microbiology (3rd edn.).Major cheese groups, Vol. 2 (pp. 349-394) London, UK: Elsevier Applied Science.

Gustaw, W., \& Mléko, S. (2007). The effect of polysaccharides and sodium chloride on physical properties of processed cheese analogs containing whey proteins. Milchwissenschaft, 62, 59-62.

Hemar, Y., Hall, C. E., Munro, P. A., \& Singh, H. (2002). Small and large deformation rheology and microstructure of ic-carrageenan gels containing commercial milk products. International Dairy Journal, 12, 371-381.

ISO 3433. (2008). Cheese - Determination of fat content - van Gulik method. Geneva, Switzerland: International Organization for Standardization.

ISO 5534. (2004). Cheese and processed cheese - Determination of the total solids content (reference method). Geneva, Switzerland: International Organization for Standardization.

ISO 8586-2. (2008). Sensory analysis - General guidance for the selection, training and monitoring of assessors - Part 2: Expert sensory assessors. Geneva, Switzerland: monitoring of assessors - Part 2: Expert senso

ISO 8589. (1988). Sensory analysis - General guidance for the design of test rooms. Geneva, Switzerland: International Organization for Standardization.

Kawasaki, Y. (2008). Influence of "creaming" on the properties of processed cheese and changes in the structure of casein during cheese making. Milchwissenschaft, $63,149-153$.

Langendorff, V., Cuvelier, G., Launay, B., Michon, C., Parker, A., \& de Kruif, C. G. (1999). Casein micelle/iota carrageenan interactions in milk: influence of temperature. Food Hydrocolloids, 13, 211-218.

Lee, S. K., Anema, S., \& Klostermeyer, H. (2004). The influence of moisture content on the Theological properties of processed cheese spreads. International Journal of Food Science and Technology, 39, 763-771.

Leroux, J., Langendorff, V., Schick, G., Vaishnav, V, \& Mazoyer, J. (2003). Emulsion stabilizing properties of pectin. Food Hydrocolloids, 17, 455-462.

Lu, Y., Shirashoji, N., \& Lucey, J. A. (2007). Rheological, textural and melting properties of commercial samples of some of the different types of pasteurized processed cheesed International Journal of Daily Technology, 60, 74-80.

Lucey, J. A., Johnson, M. E., \& Horne, D. S. (2003). Perspectives on the basis of the rheology and texture properties of cheese. Journal of Dairy Science, 86, 2725-2743.

Lynch, M. G., \& Mulvihill, D. M. (1996). Rheology of i-carrageenan gels containing caseins. Food Hydrocolloids, 10,151-157.

Mizuno, R., \& Lucey, J. A. (2007). Properties of milk protein gels formed by phosphates. Journal of Dairy Science, 90, 4524-4531.

Nakauma, M., Funami, T., Noda, S., Ishihara, S., Al-Assaf, S., Nishinari, K., et al. (2008). Comparison of sugar beet pectin, soybean soluble polysaccharide, and gum Arabic as food emulsifiers. 1. Effect of concentration, $\mathrm{pH}$, and salts on the emulsifying properties. Food Hydrocolloids, 22,1254-1267.

Nickerson, M. T., Paulson, A. T, \& Hallett, F. R. (2004). Dilute solution properties of Kcarrageenan polysaccharides: effect of potassium and calcium ions on chain conformation. Carbohydrate Polymers, 58, 25-33.

Palacios, C. (2006). The role of nutrients in bone health, from A to Z. Critical Reviews in Food Science and Nutrition, 46, 621-628. 
Palar, K., \& Sturm, R. (2009). Potential societal savings from reduced sodium consumption in the US adult population. American Journal of Health Promotion, 24 49-57.

Phillips, G. 0., \& Williams, P. A. (2000). Handbook of hydrocolloids. Boston, MA, USA: CRC Press.

Pluta, A., Ziarno, M., \& Smolinska, A. (2000). Mozliwosci zastosowania hydro- koloidow w produkcji serow topionych. Przemysl Spozywczy, 5, 42-44, (in Polish, with English abstract).

Raval, D. M., \& Mistry, V. V. (1999). Application of ultrafiltered sweet buttermilk in the manufacture of reduced fat process cheese. Journal of Daily Science, 82,2334-2343.

Rinaudo, M. (2008). Main properties and current applications of some polysaccharides as biomaterials. Polymer International, 57, 397-430.
Schaffer, B., Lorinzy, D., \& Belágyi, J. (1999). DSC and electronmicroscopic investigation of dispersion-type processed cheeses made without peptization. Journal of Thermal Analysis and Calorimetiy, 56,1211-1216.

Schaffer, B., Szakály, S., Lorinczy, D., \& Schaffer, B. (2001). Processed cheeses made with and without peptization. Journal of Thermal Analysis and Calorimetry, 64, 671 679

Tan, Y. L., Ye, A., Singh, H., \& Hemar, Y. (2007). Effects of biopolymer addition on the dynamic rheology and microstructure of renneted skim milk system. Journal of Texture Studies, 38, 404-422.

Tremlová, B., Starha, P., Buňka, F., Gistingrová, Z., \& Hrabě, J. (2006). The effect of sterilization on size and shape of fat globules in model processed cheese samples. Acta Veterinaria Brno, 75, 419-425. 